\title{
Recent patent applications in gene expression
}

\begin{tabular}{ll} 
Patent \# & Subject \\
\hline WO 2007034784 & $\begin{array}{l}\text { A connective tissue growth factor (CTGF) gene expres- } \\
\text { sion inhibitor comprising pyrrole imidazole polyamide } \\
\text { having } N \text {-methyl pyrrole, } N \text {-methyl imidazole and } \\
\text { gamma-aminobutryic acid units; useful for treating } \\
\text { CTGF-associated disease. }\end{array}$ \\
\end{tabular}

WO 2007035950

A method of screening a library of RNA interference agents to identify an RNA interference agent or a cocktail of RNA interference agents that can inhibit expression of a first target gene, involving contacting the RNA interference agent or cocktail of RNA interference agents with cells organized in a matrix and detecting a change in expression of the first target gene in the cells or a change in the cells' phenotype.

Assignee(s)
Gentier Biosystems
(Tokyo), Nihon
University (Tokyo)

B-Bridge International Eguchi Y, Mizutani (Mountain View, CA, Shibamoto $\mathrm{S}$

$9 / 23 / 2005$ USA)

US 20070036771 A method of regulating gene expression comprising introducing to gene depositories recombinant virus comprising an expression cassette including the regulatable transcription control element operably linked to an open reading frame of interest.

US 20070031356 A method of screening for a compound that modulates an effect of UV irradiation by comparing the gene expression profiles of the cell contacted with the compound before UV irradiation with those of control cells.

WO 2007045681, A method for recovering RNA from a formalin-fixed, EP 1777291 paraffin-embedded biological tissue sample for studying gene expression in tumor tissues, involving de-paraffinizing the sample, contacting with a solution containing proteinase $\mathrm{K}$, heating and adding proteinase $\mathrm{K}$.

WO 2007047706 A method for inducing expression of a target protein comprising contacting the host cell with an agent, which suppresses the nonsense mutation. This gene regulation method does not rely on the control of transcription; useful in the study of gene expression.

CN 1844387 An antisense oligonucleotide structure inhibiting expression of SIRT1 and used for treating lung, hep and pancreatic cancers.

Cardiac Pacemakers

(Minneapolis, MN, USA)

Buchwald HP, Goralczyk R, Hunziker W,

Neeb M, Riss G, Seifert N, Steiner G, Wertz K

Fundacion para la Investigacion Clinica y Molecular del Cancer de Pulmon (Barcelona, Spain)

\section{Children's Hospital}

Medical Center

(Boston, MA, USA)

Institute of Radiation

Medicine

(Beijing, PRC)

WO 2007039454

A method of silencing or attenuating expression of a target gene for conferring in plants a trait, e.g., disease resistance by introducing or expressing into the plant a chimeric ribonucleotide sequence comprising a modified ta-siRNA sequence.

US 20070089203 A new stress-responsive promoter polynucleotide useful in conferring in a plant a desired trait, preferably increased dehydration stress tolerance or increased mechanical stress tolerance.

WO 2007019062

A new isolated and purified zinc-finger polypeptide comprising a nucleotide binding region of 5 to 10 amino acid residues; useful as a gene expression regulator for treating cancer, for example.
BASF Plant Science

(Ludwigshafen,

Germany)

Bryant CJ,

Elborough KM,

Phillips JR,

Puthigae S,

Smith-Espinoza CJ,

South CR

Scripps Research

Institute (La Jolla, CA

USA)

Girouard SD, Heil RW,

$8 / 12 / 2005$

2/15/2007

Qu J, Ross J, Sih HJ, Wagner DO

Buchwald HP,

Goralczyk R,

Hunziker W,

Neeb M, Riss G,

Seifert N, Steiner G,

Wertz K

Rosell Costa RC, Taron Roca MC

10/20/2005

$10 / 19 / 2006$ $10 / 20 / 2005$

Bo $X$, Lin R, Lou $S$,

$4 / 26 / 2006$

$10 / 11 / 2006$ Sun $D$, Wang $S$

McMillan J, Ren P, 9/20/2005 9/20/2006
Song $\mathrm{H}$, Wang $\mathrm{Y}$

$6 / 30 / 2006$

$2 / 8 / 2007$

Priority Publication

Fukuda N, Sugiyama 9/20/2005 3/29/2007

H, Ueno T

